\title{
Frequent and unexplained gonadal abnormalities in whitefish (central alpine Coregonus sp.) from an alpine oligotrophic lake in Switzerland
}

\author{
D. Bernet ${ }^{1, *}$, T. Wahli ${ }^{1}$, C. Kueng ${ }^{2}$, H. Segner ${ }^{1}$ \\ ${ }^{1}$ Centre for Fish and Wildlife Health, University of Bern, Laenggass-Strasse 122, PO Box 8466, 3001 Bern, Switzerland \\ ${ }^{2}$ Fisheries Inspectorate Bern, Herrengasse 22, 3011 Bern, Switzerland
}

\begin{abstract}
The occurrence of a large number of whitefish with morphologically altered gonads in Lake Thun (Switzerland) has been reported by commercial fishermen since the year 2000. Macroscopic and microscopic examination of gonads revealed that $35 \%$ (281 out of 808) of whitefish from Lake Thun were affected. Frequency of gonadal abnormalities varied significantly with sex, age and ecotype of whitefish. Apparent females (26\% [106/408]) showed significantly less gonadal alterations than apparent males (40\% [151/225]). Fish with deformed gonads were observed in all age classes from 1 to $6 \mathrm{yr}$, but were most frequent in the year classes $3+$ to $5+$. The gonadal alterations showed different frequencies among the 3 ecotypes of whitefish living in the lake: 1 ecotype was less affected $(26 \%)$ than the other 2 forms ( $41 \%$ and $32 \%$, respectively). The gonadal alterations included adhesions/fusions to the peritoneal wall and the lateral trunk musculature (overall: $5 \%$; in females: $5 \%$; in males: $5 \%)$, asymmetry $(4 \% ; 6 \% ; 4 \%)$, atrophy $(4 \% ; 6 \% ; 1 \%)$, compartmentations $(11 \% ; 4 \% ; 18 \%)$, constrictions $(3 \% ; 1 \% ; 7 \%)$ and hermaphroditism $(1.1 \%$ of sampled fish, and 10 additional specimes collected by fishermen during the filleting process). In some cases, more than one alteration was observed in the same fish. Hermaphroditism manifested as 3 different types: (1) the lobular type, in which a consecutive sequence of testicular and ovarian lobes are found on the same gonad strand; (2) discrete gonads within one fish, with one gonad strand being ovarian tissue and the other being testicular tissue; and (3) the mosaic type, in which oocytes lie in tissue with normal testicular morphology, or spermatids or sperm are present in ovarian tissue. Several features of the gonadal alterations described in this study of whitefish from Lake Thun have also been reported for whitefish from other areas. However, the Lake Thun situation appears to be unique because of the high prevalence of fish affected and the broad variation of abnormal features. The causes of the frequent appearance of these gonadal alterations in whitefish from Lake Thun remain unclear.
\end{abstract}

KEY WORDS: Hermaphroditism · Whitefish · Intersex $\cdot$ Gonads · Reproduction · Disease

Resale or republication not permitted without written consent of the publisher

\section{INTRODUCTION}

Lake Thun is an alpine, oligotrophic lake of $47 \mathrm{~km}^{2}$ with a maximal depth of $217 \mathrm{~m}$ (see Fig. 1 for location). Whitefish Coregonus sp. represent the main fish species used by commercial fishermen, with an annual catch of 20 to 50 tons. Several morphologically different ecotypes of whitefish have been observed in the lake (Steinmann 1951, Kottelat 1997, Douglas \& Brunner 2002).
In the year 2000, professional fishermen observed a large number of individuals with gross gonadal morphology alterations among the fish caught in the lake. In previous years, no corresponding alterations in Lake Thun's coregonids had been observed by the fishermen. The apparently sudden onset and frequent occurrence of gonadal alterations in coregonids from Lake Thun gave rise to concerns about possible causes and potential consequences for future stock replenishment. Insufficient knowledge of 


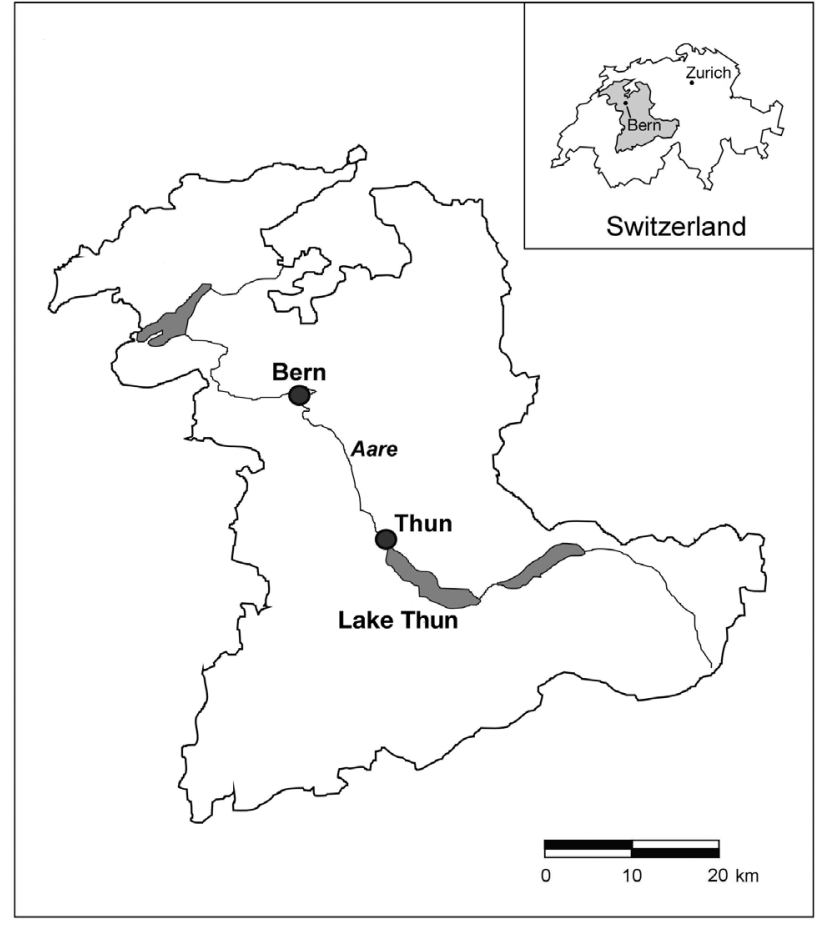

Fig. 1. Location of Lake Thun

fish gonad morphology makes it difficult to discriminate between normal and pathological changes, thereby obstructing accurate assessment of the degree of alteration within populations. Alterations of gross gonadal morphology have been reported for a number of fish species at various locations in Europe (Sandström et al. 1988, Norrgren et al. 1994, Wicklund et al. 1996, Jobling et al. 1998), North America (Ruby \& Cairns 1983, Hunter \& Macewicz 1995, Fitzsimons \& Cairns 2000, Mikaelian et al. 2002) and New Zealand (Kinnison et al. 2000). In many of these cases, the etiology of gonadal malformation is not known. It is well established, however, that gonad morphology and differentiation in fish is susceptible to a variety of environmental factors such as temperature (Patino et al. 1996, Kitano et al. 1999, Goto et al. 2000, Baroiller \& Guiguen 2001), parasites (Wicklund \& Bylund 1994) or chemical substances, both compounds with endocrine activity (Jobling et al. 1998, Rodgers-Gray et al. 2000, Noaksson et al. 2001, Matthiessen et al. 2002, Vethaak et al. 2002) and compounds with other modes of toxic action (Johnson et al. 1998, Kime 1998). To advance our currently still fragmentary knowledge of gonadal malformations and their etiology in wild fish populations, a careful documentation of case studies on gonad aberrations in wild fish stocks is an important requirement (Blazer 2002).
To the best of our knowledge, there are no reports describing normal differentiation and morphology of coregonid gonads. However since Salmoniformes contain differentiated gonochoristic species, coregonids may follow this developmental pattern as well (Kinnison et al. 2000). There have been occasional observations of gonadal alterations in coregonid species; however, the reported frequencies were always low (i.e. Chen 1969, Edsall 1970, Porter \& Corey 1974, Scott 1975, Brown \& Scott 1988, Kinnison et al. 2000). When confronted for the first time with the gonadal alterations of whitefish from Lake Thun, an email inquiry was made to several international Coregonid experts to investigate whether similar changes at comparable frequencies had been observed elsewhere (Escher 2001). Responses suggest that the gonadal alterations in whitefish from Lake Thun are unique with respect to both the simultaneous presence of a large variety of gonadal alterations, and their high frequency. This case report aims to provide a macroscopical and microscopical documentation of the gonadal alterations, and an estimation of their relative frequency. The results will add to the database of gonadal malformations of wild fish, and will provide the basis for the further exploration of the phenomenon.

\section{MATERIALS AND METHODS}

Gonads were examined from 818 whitefish from Lake Thun sampled between August 2000 and August 2003. All samples came from gillnetting hauls of professional fishermen. Material, numbers, origin, purpose and mode of examination of the samples are listed in Table 1 and are briefly described below.

The first 10 gonad samples were received on 21 August and 6 October 2000. These were selected by the fishermen as a representative sample of the various gonadal abnormalities commonly observed during filleting. The fishermen preserved the suspect gonads in $4 \%$ buffered formalin and sent the material to our institute for further examination.

For subsequent sampling, Lake Thun whitefish were obtained from 2 sources. Firstly, individuals were selected at random from commercial hauls ( $\mathrm{n}=44$ ). Secondly, we received fish from a routine monitoring programme executed by the Fisheries Inspectorate of Bern. This monitoring programme included a monthly sampling of 25 whitefish. Besides the determination of length, weight and age (scale reading) these fish were also dissected for examination of gonadal alterations. This programme provided the present study with data from February 2001 to August 2003 from a total of 764 fish. 
Table 1. Coregonus sp. Details of samples from Lake Thun

\begin{tabular}{|c|c|c|c|c|c|c|}
\hline $\begin{array}{l}\text { Date of } \\
\text { receipt }\end{array}$ & $\begin{array}{l}\text { Sample } \\
\text { size }\end{array}$ & Material & $\begin{array}{l}\text { Length of } \\
\text { fish }(\mathrm{cm})\end{array}$ & $\begin{array}{l}\text { Weight of } \\
\text { fish }(g)\end{array}$ & Origin and purpose & Examinations \\
\hline 21 Aug 2000 & 4 & $\begin{array}{l}\text { Formalin-preserved } \\
\text { gonads }\end{array}$ & - & - & $\begin{array}{l}\text { Selection of altered } \\
\text { gonads observed } \\
\text { during filleting by } \\
\text { professional fishermen; } \\
\text { not used for prevalence } \\
\text { determination of gonad } \\
\text { alterations }\end{array}$ & $\begin{array}{l}\text { Macroscopy and } \\
\text { histology }\end{array}$ \\
\hline 6 Oct 2000 & 6 & $\begin{array}{l}\text { Formalin-preserved } \\
\text { gonads }\end{array}$ & $26.6-29.3$ & $164-250$ & $\begin{array}{l}\text { Selection of altered } \\
\text { gonads observed } \\
\text { during filleting by } \\
\text { professional fishermen; } \\
\text { not used for prevalence } \\
\text { determination of gonad } \\
\text { alterations }\end{array}$ & $\begin{array}{l}\text { Macroscopy and } \\
\text { histology }\end{array}$ \\
\hline 22 Jun 2001 & 17 & Entire fish & $25.0-28.0$ & - & $\begin{array}{l}\text { Random sample from a } \\
\text { haul; used for prevalence } \\
\text { determination of gonad } \\
\text { alterations }\end{array}$ & $\begin{array}{l}\text { Macroscopy and } \\
\text { histology }\end{array}$ \\
\hline 14 Aug 2001 & 7 & Entire fish & $23.5-30.7$ & $125-285$ & $\begin{array}{l}\text { Random sample from a } \\
\text { haul; used for prevalence } \\
\text { determination of gonad } \\
\text { alterations }\end{array}$ & $\begin{array}{l}\text { Macroscopy and } \\
\text { histology }\end{array}$ \\
\hline 18 Dec 2001 & 20 & Entire fish & $25.0-29.5$ & $127-235$ & $\begin{array}{l}\text { Random sample from a } \\
\text { haul; used for prevalence } \\
\text { determination of gonad } \\
\text { alterations }\end{array}$ & Macroscopy \\
\hline $\begin{array}{l}\text { Feb } 2001 \text { to } \\
\text { Aug } 2003\end{array}$ & $31 \times 25^{\mathrm{a}}$ & $\begin{array}{c}\text { Formalin-preserved } \\
\text { gonads }\end{array}$ & $15.9-45.0$ & 69-1066 & $\begin{array}{l}\text { Random samples from } \\
\text { monthly monitoring } \\
\text { programme; Feb } 2001 \text { to } \\
\text { Aug } 2003 \text { ( } 31 \text { mo); used } \\
\text { for prevalence determina- } \\
\text { tion of gonad alterations }\end{array}$ & Macroscopy \\
\hline
\end{tabular}

Gonads dissected from whitefish were first examined macroscopically, and subsequently preserved in $4 \%$ buffered formalin. For those processed for histological examination, pieces of the gonads were embedded in paraffin wax, cut into $4 \mathrm{~mm}$ thick sections and stained with haematoxylin-eosin (Table 1).

Apart from the selection of alterated gonads collected by the professional fisherman during the filleting process (see above), samples from the hauls and from the monthly routine programme allowed the prevalence of the alterations to be determined (Table 1).

The gonadal alterations were grouped according to the sex, age and ecotype of whitefish. The ecotype of whitefish is based on ecological, phenotypic and/or genetic criteria, and may be evaluated using several distinct approaches (Steinmann 1951, Kottelat 1997, Douglas \& Brunner 2002). To simplify the nomenclature in this study, we used Steinmann's ecotype assignments exclusively. Three ecotypes of Coregonus sp. in
Lake Thun were distinguished using gill racker counting. The local names are 'Kropfer' (17 to 24 gill rackers), 'Albock' (25 to 35) and 'Brienzlig' (36 to 42). Gender- and ecotype-related differences in the prevalences of gonadal alterations were checked with a $\chi^{2}$ test. A p value of $\leq 0.05$ was considered as significant.

\section{RESULTS}

\section{Description of normal gonads in whitefish}

Females. Whitefish ovaries are located in pairs dorsally in the peritoneal cavity, ventrolaterally attached to the swim bladder. In the prespawning stage, the ovarian strands contain ovarian follicles and are surrounded by a smooth, translucent, fibrinous layer. In the spawning stage, ovulated eggs fill up the whole body cavity. An oviduct is not present in whitefish, but 
the eggs are released into the water through the genital pore behind the anus.

Normally differentiated ovaries were observed in $74 \%$ of female whitefish from Lake Thun (Table 2).

Males. Like the ovaries in females, the male testes lie dorsally in pairs in the peritoneal cavity, ventrolaterally attached to the swim bladder. Cross-sections of the testes are triangular. Both strands of the testes lead into efferent ducts (Ductus deferens), which fuse at the end of the swim bladder and continue to a location posterior to the vent. In the prespawning stage the testes are, at most, half the length of the peritoneal cavity and cranially located. When mature, the testes take up the whole body cavity. Sometimes this cranially located major lobe of the testical strand is accompanied by a smaller caudally located part. Both parts are connected by a duct. Such a division of the testicular strand into 2 lobes was repeatedly found in whitefish of Lake Thun,

Table 2. Coregonus sp. Whitefish from Lake Thun with gonadal alterations

\begin{tabular}{|lccc|}
\hline Gender & $\begin{array}{c}\text { Normal } \\
\text { gonads }\end{array}$ & $\begin{array}{c}\text { Abnormal } \\
\text { gonads }\end{array}$ & Total \\
\hline Females & 302 & 106 & 408 \\
& $(74 \%)$ & $(26 \%)$ & $(100 \%)$ \\
Males & 225 & 151 & 376 \\
& $(60 \%)$ & $(40 \%)$ & $(100 \%)$ \\
Juvenile (normal)/ & 7 & 8 & 15 \\
undetermined & & & \\
bilateral atrophy & - & 19 & 19 \\
Hermaphrodites & 534 & 284 & 818 \\
Total & $(65 \%)$ & $(35 \%)$ & $(100 \%)$ \\
& & & \\
\hline
\end{tabular}

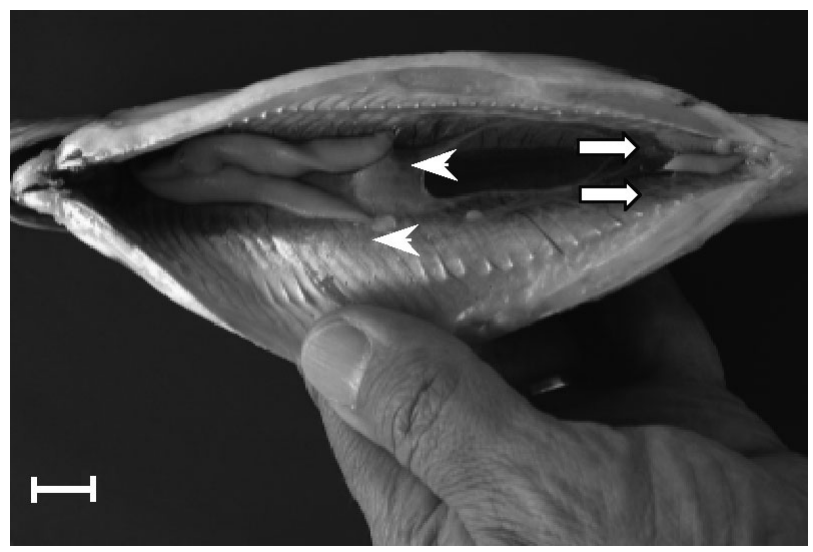

Fig. 2. Coregonus sp. Normally developed testes of a male whitefish in the prespawning stage. Note the larger cranial part (arrowheads) and the smaller caudal part next to the anal pore (arrows). Scale bar $=1 \mathrm{~cm}$ which we considered as normal in contrast to compartmentations and constrictions (Fig. 2).

Normally developed testes were observed in $60 \%$ of male whitefish from Lake Thun (Table 2).

\section{Gonadal abnormalities}

The 10 initially selected whitefish, as well as $35 \%$ (281 out of 808 ) of the whitefish from the hauls and the monitoring programme, showed gonadal alterations. The malformations can be categorised as asymmetries, atrophy, compartmentations, constrictions, adhesions/ fusions and hermaphroditism. Simultaneous occurrence of multiple alterations could be seen within the same fish (3\%). Affected fish were present in all age classes from 1 to 6 yr (Fig. 3). The highest prevalence, however, occurred in 3- to 5-yr-old fish. Additional data will be needed to verify whether this age distribution of affected fish is based on cohorts or not. The ecotype locally named 'Albock' (26\% abnormal specimens) was statistically less affected than the 'Brienzlig' ecotype (41\% affected fish) (Table $3, \chi^{2}$ test; $\chi^{2}=18.9$; $\mathrm{df}=1 ; \mathrm{p}<0.01)$. Males were significantly more affected than females (Table $2, \chi^{2}$ test $\chi^{2}=17.9 ; \mathrm{df}=1$; $\mathrm{p}<0.01)$.

The macroscopical and microscopical features of gonadal alterations present in whitefish of Lake Thun are described in the following paragraphs.

Compartmentation and constrictions. A division of the gonads in male fish into several lobes, connected with the sperm duct, was defined as compartmentation (Fig. 4). Whereas the division of a testicular strand into

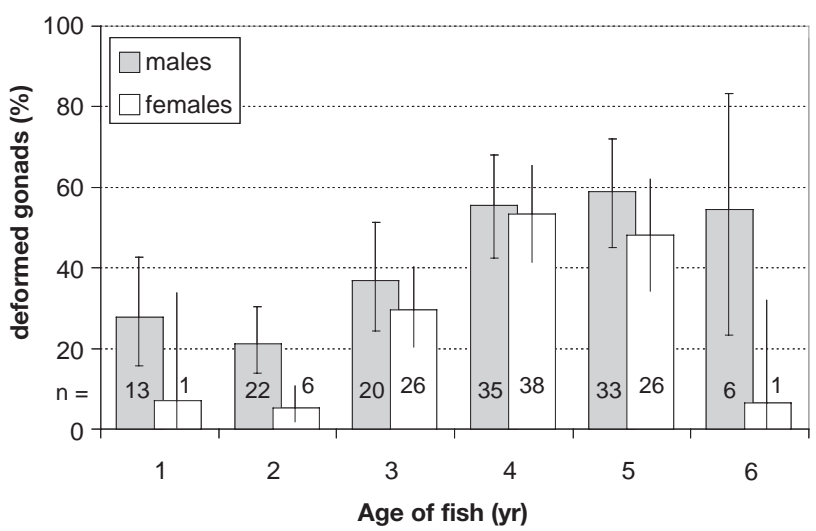

Fig. 3. Coregonus sp. Prevalence of gonadal alterations in whitefish from Lake Thun grouped by age, based on whitefish sampled from hauls and the monthly monitoring programme ( $\mathrm{n}=808$ ). Gonads were considered as deformed if one or more of the following alterations were present: atrophy, asymmetry, compartmentation, constriction, adhesion/ fusion with peritoneal wall or hermaphroditism. Error bars represent the $95 \%$ confidence limits of the binomial distribution 
Table 3. Coregonus sp. Prevalence of abnormal gonads in the 3 different ecotypes living in Lake Thun

\begin{tabular}{|lcccc|}
\hline $\begin{array}{l}\text { Whitefish } \\
\text { ecotype }\end{array}$ & $\begin{array}{c}\text { Gill } \\
\text { rackers }\end{array}$ & Normal & Abnormal & Total \\
\hline 'Kropfer' & $18-24$ & $\begin{array}{c}17 \\
(68 \%)\end{array}$ & $\begin{array}{c}8 \\
(32 \%)\end{array}$ & 25 \\
'Albock' & $25-35$ & $\begin{array}{c}296 \\
(74 \%)\end{array}$ & $\begin{array}{c}105 \\
(26 \%)\end{array}$ & 401 \\
'Brienzlig' & $36-42$ & $\begin{array}{c}201 \\
(59 \%)\end{array}$ & $\begin{array}{c}141 \\
(41 \%)\end{array}$ & 342 \\
& & 20 & 30 & 50 \\
undetermined & & $(40 \%)$ & $(60 \%)$ & \\
agill rackers not counted & & & \\
\hline
\end{tabular}

a major cranial part and a smaller caudal lobe is assumed to be a normal feature in whitefish in the premature stage (see Meder 1984), the compartmentations in male whitefish from Lake Thun are characterised by division into more than 2 lobes. This was observed in 69 male fish. In females, a compartmentation of the ovaries was less frequent (18 specimens; Table 4) and never exceeded a division into more than 2 lobes.

Constrictions of the testis (Fig. 5) were observed in 25 males. Constrictions were defined as a segmentation of the lobes, whereby lobes were not reduced to the sperm duct but testicular tissue was still present in the intersectional part. In females, only 3 fish showed constrictions in the ovaries.

Constrictions and compartmentations were found on both gonad strands within a fish, but they could also occur on only 1 of the 2 strands. Histologically, the tubules in the region of a constriction were slightly com- pressed and their walls proliferated, but no other lesions were seen.

Asymmetry/atrophy. A total of 23 females and 13 males showed asymmetrically developed gonads, i.e. 1 of the 2 gonad strands was clearly thinner and shorter (Table 4). In females, gonad strand underdevelopment was frequently accompanied by rounding of the smaller gonad strand (Fig. 6).

Twenty-five females and 3 males revealed not only a shortening, but also a total atrophy of 1 strand. In 10 fish (length: 27.5 to $31 \mathrm{~cm}$; weight: 179 to $302 \mathrm{~g}$; age: 3 to $5 \mathrm{yr}$ ) neither strand was developed (bilateral atrophy) and, hence, the sex could not be determined (Table 4).

Adhesion/fusion of the gonads with the peritoneal wall. Nineteen males and 22 females showed gonads fused with the peritoneal wall (Table 4, Fig. 7). Generally, attached lobes were restricted to compartmented gonads, or to gonad strands reduced in size. In some fish, the fused gonads were completely surrounded by a thick layer of connective tissue. Macroscopically, these encapsulated gonads seemed to have grown into the lateral trunk musculature (Fig. 8). Fusions with the peritoneal wall were also observed in hermaphrodites (see next section)

Hermaphroditism. Examinations revealed hermaphroditism in 19 whitefish specimens (Table 4). Ten of the hermaphroditic fish originated from the selection of altered gonads by the professional fishermen during the filleting process. One case was detected in a fish from a haul, and 8 were found in the material from the monthly monitoring programme. Affected fish were 27 to $34.5 \mathrm{~cm}$ in length, weighed 164 to $373 \mathrm{~g}$ and were 2 to 6 yr old.

Three distinct morphological patterns of hermaphroditism could be distinguished:
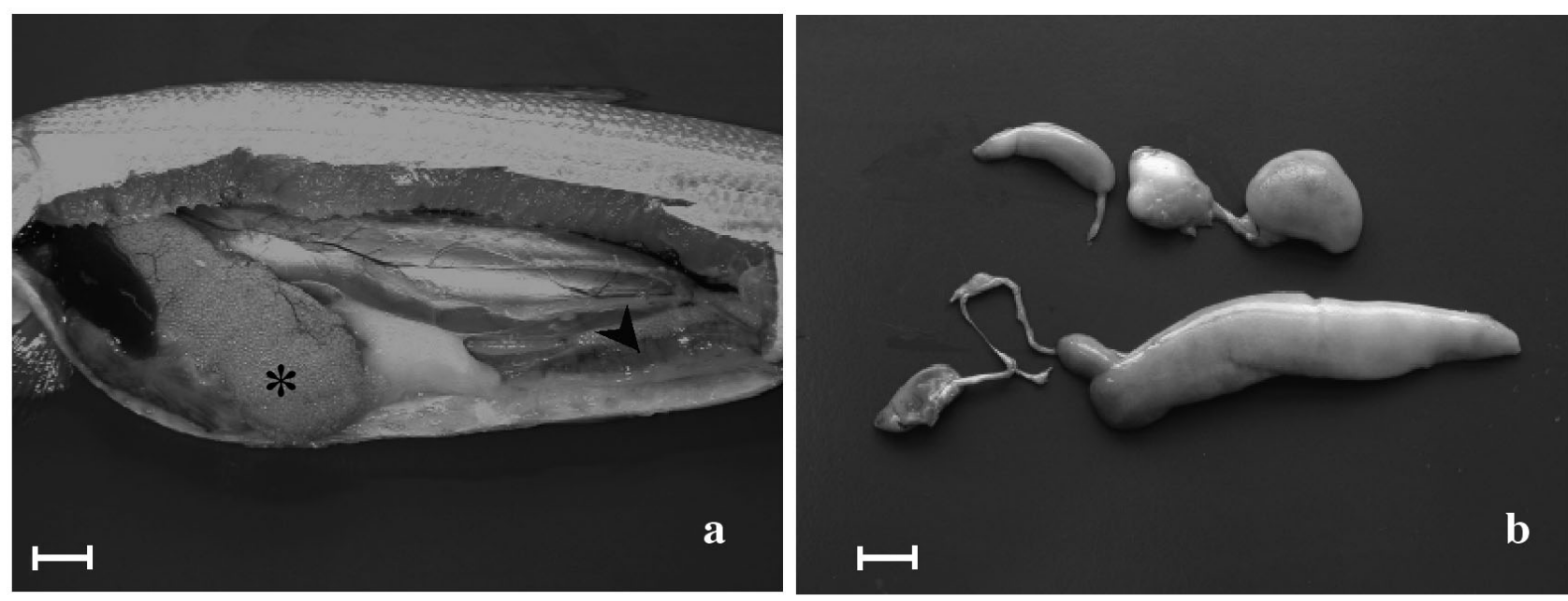

Fig. 4. Coregonus sp. Compartmentation of gonads. (a) Ovaries of a female divided into a major cranial part (asterisk) and a smaller caudal part (arrowhead). (b) Testes with 1 strand divided into 3; the other is divided into 2 lobes, which are connected by the sperm duct. Scale bars $=1 \mathrm{~cm}$ 
Table 4. Coregonus sp. Prevalence of deformed gonads in whitefish from Lake Thun from different sampling regimes. Because of the simultaneous occurrence of multiple alterations within $1 \mathrm{fish}$, the total pathologies detected are greater than the number of fish sampled

\begin{tabular}{|c|c|c|c|c|c|c|c|c|c|c|}
\hline \multirow[t]{2}{*}{ Gonads } & \multirow[t]{2}{*}{$\begin{array}{c}\text { Selection of altered gonads } \\
\text { (Dates of receipt: } 21 \text { Aug } 00^{\text {and } 6 \text { Oct } 00)^{\mathrm{a}}}\end{array}$} & \multicolumn{3}{|c|}{$\begin{array}{l}\text { Samples from hauls } \\
\text { (Dates of receipt: } 22 \text { Jun 01, } \\
14 \text { Aug } 01 \text { and } 18 \text { Dec } 01)^{b}\end{array}$} & \multicolumn{3}{|c|}{$\begin{array}{l}\text { Samples from the monthly } \\
\text { routine programme } \\
\text { (Feb } 2001 \text { to Aug 2003) }^{\mathrm{a}}\end{array}$} & \multicolumn{3}{|c|}{$\begin{array}{l}\text { Total samples from } \\
\text { hauls and monthly } \\
\text { routine programme }\end{array}$} \\
\hline & & $\begin{array}{c}\text { Females } \\
\mathrm{n}=12\end{array}$ & $\begin{array}{l}\text { Males } \\
\mathrm{n}=31\end{array}$ & $\begin{array}{l}\text { Hermaphr. } \\
\quad \mathrm{n}=1\end{array}$ & $\begin{array}{l}\text { Females } \\
\mathrm{n}=396\end{array}$ & $\begin{array}{c}\text { Males } \\
\mathrm{n}=343\end{array}$ & $\begin{array}{l}\text { Others }^{\mathrm{d}} \\
\mathrm{n}=25\end{array}$ & $\begin{array}{c}\text { Females } \\
\mathrm{n}=408\end{array}$ & $\begin{array}{l}\text { Males } \\
\mathrm{n}=374\end{array}$ & $\begin{array}{l}\text { Others }^{\mathrm{d}} \\
\mathrm{n}=26\end{array}$ \\
\hline $\begin{array}{l}\text { Normal } \\
\text { development }\end{array}$ & & $\begin{array}{c}6 \\
(50 \%)\end{array}$ & $\begin{array}{c}14 \\
(45 \%)\end{array}$ & & $\begin{array}{c}296 \\
(75 \%)\end{array}$ & $\begin{array}{c}211 \\
(62 \%)\end{array}$ & $\begin{array}{c}7 \\
(1 \%)^{\mathrm{e}}\end{array}$ & $\begin{array}{c}302 \\
(74 \%)\end{array}$ & $\begin{array}{c}225 \\
(60 \%)\end{array}$ & $\begin{array}{c}7 \\
(1 \%)^{\mathrm{e}}\end{array}$ \\
\hline Asymmetry & & $\begin{array}{c}5 \\
(42 \%)\end{array}$ & $\begin{array}{c}5 \\
(16 \%)\end{array}$ & & $\begin{array}{c}18 \\
(5 \%)\end{array}$ & $\begin{array}{c}8 \\
(2 \%)\end{array}$ & & $\begin{array}{c}23 \\
(6 \%)\end{array}$ & $\begin{array}{c}13 \\
(4 \%)\end{array}$ & \\
\hline $\begin{array}{l}\text { Atrophy: } \\
\text { unilateral }\end{array}$ & & $\begin{array}{c}1 \\
(8 \%)\end{array}$ & & & $\begin{array}{c}24 \\
(6 \%)\end{array}$ & $\begin{array}{c}3 \\
(1 \%)\end{array}$ & & $\begin{array}{c}25 \\
(6 \%)\end{array}$ & $\begin{array}{c}3 \\
(1 \%)\end{array}$ & \\
\hline bilateral & & & & & & & $\begin{array}{c}10 \\
(1 \%)^{\mathrm{e}}\end{array}$ & & & $\begin{array}{c}10 \\
(1 \%)^{\mathrm{e}}\end{array}$ \\
\hline $\begin{array}{l}\text { Compart- } \\
\text { mentation }\end{array}$ & & & $\begin{array}{c}7 \\
(23 \%)\end{array}$ & & $\begin{array}{c}18 \\
(5 \%)\end{array}$ & $\begin{array}{c}62 \\
(18 \%)\end{array}$ & & $\begin{array}{c}18 \\
(4 \%)\end{array}$ & $\begin{array}{c}69 \\
(18 \%)\end{array}$ & \\
\hline Constriction & & & $\begin{array}{c}7 \\
(23 \%)\end{array}$ & & $\begin{array}{c}3 \\
(1 \%)\end{array}$ & $\begin{array}{c}18 \\
(5 \%)\end{array}$ & & $\begin{array}{c}3 \\
(1 \%)\end{array}$ & $\begin{array}{c}25 \\
(7 \%)\end{array}$ & \\
\hline $\begin{array}{l}\text { Adhesion/fusion } \\
\text { to the peritoneal } \\
\text { cavity }\end{array}$ & 2 & $\begin{array}{c}1 \\
(8 \%)\end{array}$ & $\begin{array}{c}5 \\
(16 \%)\end{array}$ & & $\begin{array}{c}21 \\
(5 \%)\end{array}$ & $\begin{array}{c}14 \\
(4 \%)\end{array}$ & & $\begin{array}{c}22 \\
(5 \%)\end{array}$ & $\begin{array}{c}19 \\
(5 \%)\end{array}$ & \\
\hline $\begin{array}{l}\text { Abnormal, but } \\
\text { not specified }\end{array}$ & & & & & $\begin{array}{c}23 \\
(6 \%)\end{array}$ & $\begin{array}{c}33 \\
(10 \%)\end{array}$ & & $\begin{array}{c}23 \\
(6 \%)\end{array}$ & $\begin{array}{c}33 \\
(9 \%)\end{array}$ & \\
\hline \multicolumn{11}{|l|}{ Hermaphroditism: } \\
\hline total & 10 & & & $\begin{array}{c}1 \\
(2 \%)^{\mathrm{e}}\end{array}$ & & & $\begin{array}{c}8 \\
(1 \%)^{\mathrm{e}}\end{array}$ & & & $\begin{array}{c}9 \\
(1 \%)^{\mathrm{e}}\end{array}$ \\
\hline lobular type & 4 & & & 1 & & & 1 & & & $\begin{array}{c}2 \\
(0 \%)^{\mathrm{e}}\end{array}$ \\
\hline mosaic type & 5 & & & & & & & & & \\
\hline sexually discrete type & 6 & & & & & & 1 & & & $\begin{array}{c}1 \\
(0 \%)^{\mathrm{e}}\end{array}$ \\
\hline \multicolumn{11}{|c|}{${ }^{a}$ Formalin-preserved material } \\
\hline \multicolumn{11}{|c|}{$\begin{array}{l}\text { 'Percentages were calculated referring to whitefish from hauls and the monthly routine programme, but not to the selection of gonad } \\
\text { anomalies from the commercial fishermen }\end{array}$} \\
\hline
\end{tabular}

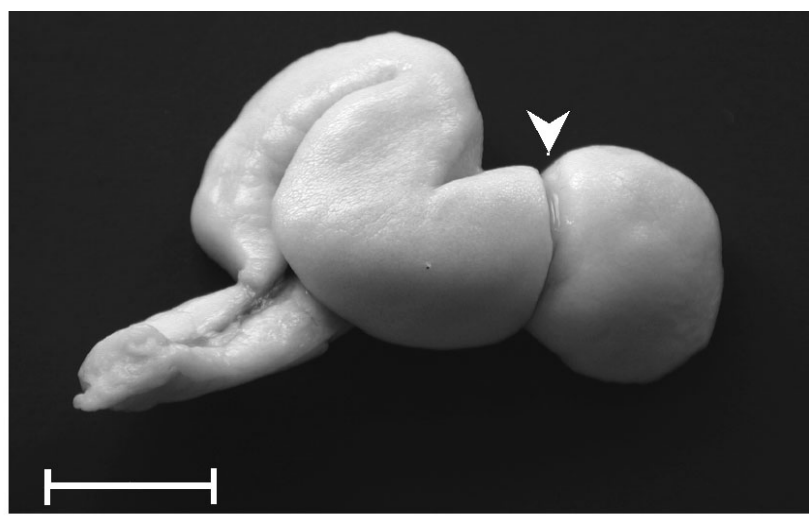

Fig. 5. Coregonus sp. Constriction (arrowheads) in a testis of a male. Note the severe distortion of the testes strand. Scale bar $=1 \mathrm{~cm}$

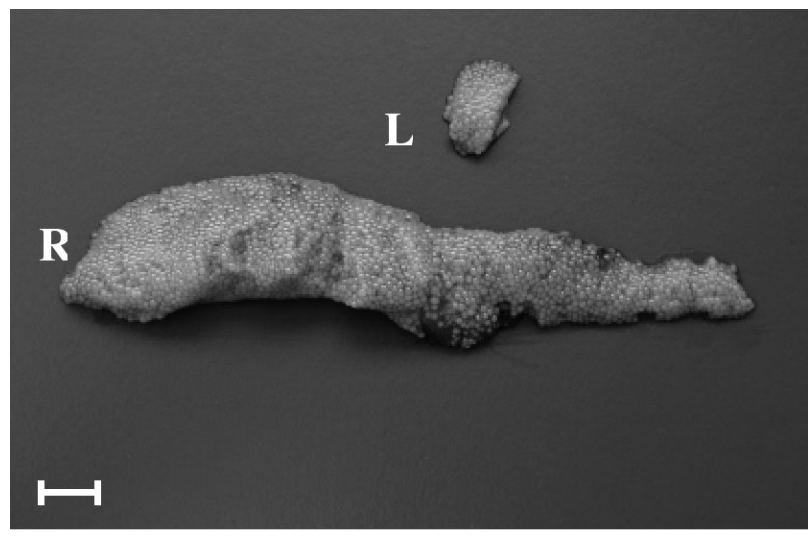

Fig. 6. Coregonus sp. Severe asymmetry of the 2 ovarian strands of a female. L: left; R: right. Scale bar $=1 \mathrm{~cm}$ 

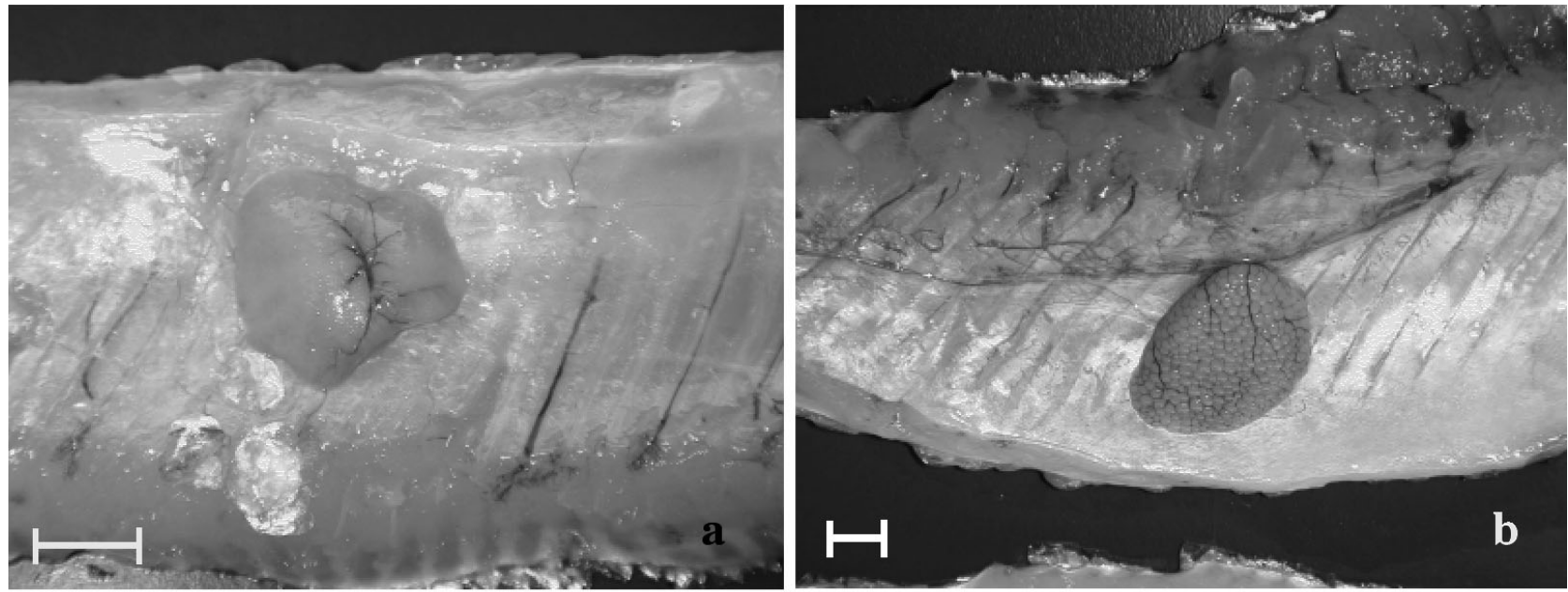

Fig. 7. Coregonus sp. Adhesion of gonad lobes at the peritoneal wall. (a) Testis, (b) ovary. Scale bars $=1 \mathrm{~cm}$
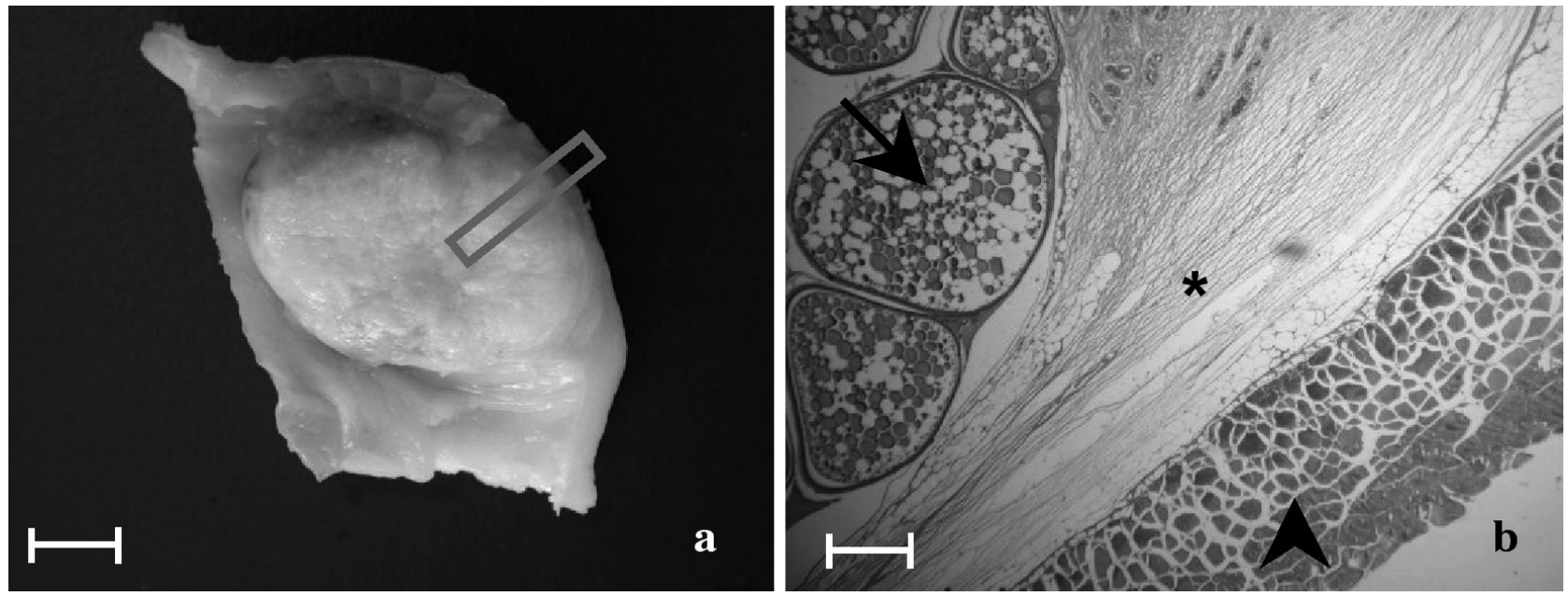

Fig. 8. Coregonus sp. Fusion of the gonads with the peritoneal wall. (a) Lateral trunk musculature of a female whitefish with an encysted lobe of the ovaries. The inlay represents the histological section shown in b. Scale bar $=1 \mathrm{~cm}$. (b) Histological section of an encysted ovarian lobe (HE staining). The ovarian lobe (secondary oocytes with vitellogenic deposits; arrow) is encapsulated by a prominent layer of connective tissue (asterisk) and fused with the muscles of the lateral musculature (arrowhead). Scale bar $=2.5 \mathrm{~mm}$

Lobular type. This pattern of hermaphroditism, observed in 6 specimens, was characterised by a consecutive sequence of testicular and ovarian tissue on the same gonad strand (Fig. 9). The transition between testicular and ovarian tissue was immediate or was marked by constrictions or even by a separation of both sexes with a thin duct. Histologically both the ovarian and the testicular tissues had a normal appearance with partly mature sperm and oocytes.

Mosaic type. This pattern of hermaphroditism was diagnosed histologically in 5 specimens. Single primary or secondary oocytes were scattered throughout testicular areas (Fig. 10) (2 fish) or alternatively, mature sperma- tozoids were present in ovarian tissue (3 fish). Whereas an artificial contamination of ovarian tissue with sperm during tissue sampling cannot be fully excluded, the presence of spermatogonia embedded in ovarian tissue suggests that these findings were not artefacts.

The mosaic pattern of intersexuality was found in 1 hermaphrodite of the lobular type and in 4 hermaphrodites with a bilateral distribution of the ovarian and testicular strand, but never in macroscopically sexed males or females.

Sexually discrete strands type. Seven specimens showed sexually discrete gonad strands. Histologically, both the ovarian and the testicular tissue showed normal development with partly mature sperms and oocytes. 

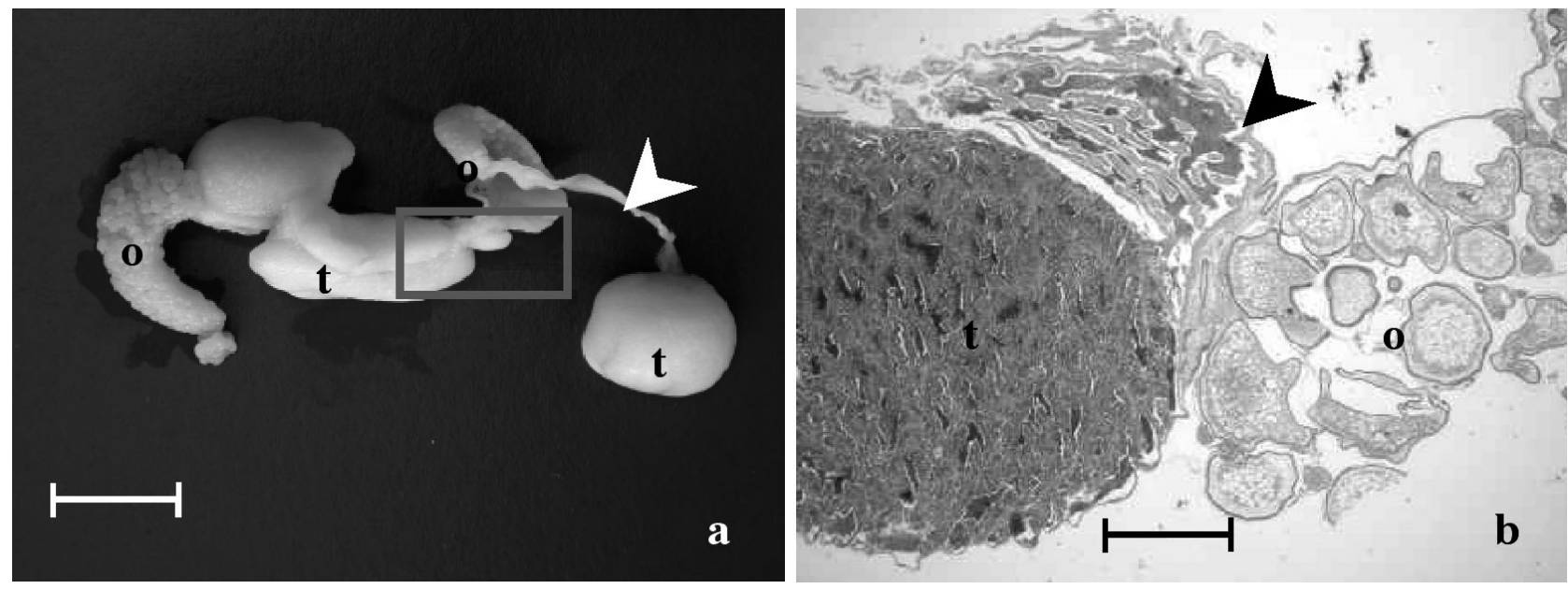

Fig. 9. Coregonus sp. Gonad strand of a hermaphrodite. (a) Lobular type with ovarian (o) and testicular (t) tissue on one strand. The parts of different sexual tissues are separated by constrictions or connected with the sperm duct (arrowhead). Scale bar $=$ $1 \mathrm{~cm}$. (b) HE-stained histological section (see inlay in a). The tubules of the testicular tissue (t) and the sperm duct (arrowhead) are filled with ripe sperm (basophilic areas). The ovarian tissue (o) consists of secondary oocytes with few vitellogenic droplets. Scale bar $=2 \mathrm{~mm}$

Histological alterations. Out of the 401 coregonids examined macroscopically for gonadal alterations, 54 were additionally investigated by light microscopy. Thirty-nine of the 54 histologically examined gonad samples (with and without macroscopical alterations) from Lake Thun were normally developed. Most of them were in the prespawning phase or even mature. The sexual products did not show any visible malformations, neither in hermaphroditic fish nor in fish with other macroscopical alterations. However, histological alterations included the following: single to multiple granulomas (3 fish), partly filled with necrotic, haemorrhagic areas and partly with calcareous casts; haemor-

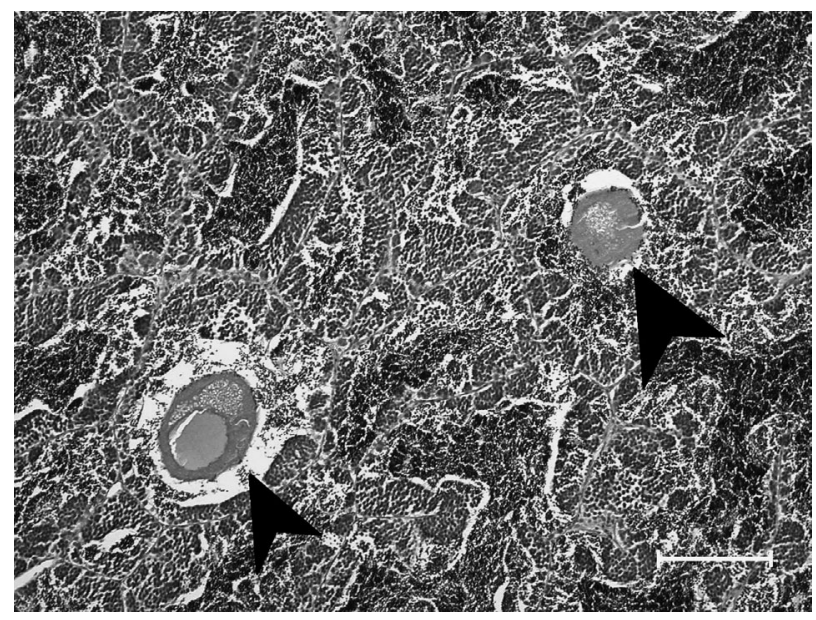

Fig. 10. Coregonus sp. Mosaic intersex. Two primary oocytes (arrowheads) are embedded in testicular tissue. The tubules of the testes are partly filled with mature sperm (basophilic areas). Scale bar $=100 \mathrm{~mm}$ rhages (9 fish) or focal necrotic areas (1 fish); thickened tubular walls (4 fish); lymphocytic infiltration (1 fish); hyperplasia of the collagenous layer of the sperm duct and fusion with the peritoneal layer of the lateral trunk musculature (1 fish); and gonads surrounded with a thick layer of collagenous fibres (3 fish). No parasitic infestations were observed.

\section{DISCUSSION}

The gonadal alterations of whitefish from Lake Thun include adhesions/fusions to the trunk musculature, atrophy, asymmetry, compartmentations, constrictions and hermaphroditism. The phenomenon of hermaphroditism has been reported from most areas inhabited by coregonids and appears to be unrelated to a certain location or geographical region (Table 5). In Switzerland, to our knowledge, the oldest record of hermaphroditic whitefish dates back to 1927 (Florin 1945). Since then, in most of the larger lakes of Switzerland, including Lake Geneva (Florin 1945, D. Gerdeaux pers. comm.), Lake Biel (Steinmann 1948), Lake Brienz (A. Kirchhofer pers. comm.), Lake Lucerne (R. Mueller pers. comm.), Lakes Constance and Walen (Ruhlé 1983), single hermaphroditic coregonids have been found. However, no reports are available to date on hermaphroditic whitefish in Lake Thun, although whitefish in this lake have been thoroughly investigated (Kirchhofer 1995, Kirchhofer \& Lindt-Kirchhofer 1998) and gonads of these fish have also been analysed for maturity assessments (A Kirchhofer pers. comm.). 
Table 5. Coregonus sp. Published cases of hermaphroditism in whitefish

\begin{tabular}{|c|c|c|c|c|}
\hline Source & Species & Location, Country & Arrangement & Prevalence \\
\hline Florin (1945) & C. schinzii fera & Lake Geneva, Switzerland & Lobular type & Single case \\
\hline Steinmann (1948) & Coregonus sp. & Lake Biel, Switzerland & Lobular type & Single case \\
\hline Chen (1969) & C. clupeaformis & Newfoundland, Canada & Lobular type & $\begin{array}{l}\text { Single case } \\
(1 \text { out of } 261)\end{array}$ \\
\hline Edsall (1970) & C. hoyi & Lake Michigan, USA & Lobular and mosaic type & Single case \\
\hline $\begin{array}{l}\text { Statova \& } \\
\text { Tomnatik (1970) }\end{array}$ & C. peled & ?, former USSR & Hermaphrodite & Single case \\
\hline $\begin{array}{l}\text { Porter \& } \\
\text { Corey (1974) }\end{array}$ & C. clupeaformis & Lake Huron, Canada & Lobular and mosaic type & Single case \\
\hline Scott (1975) & C. lavaretus & Loch Lomond, Scotland & Mosaic type & $\begin{array}{l}\text { Single case } \\
\text { (1 out of } 10000)\end{array}$ \\
\hline Semenov (1980) & C. peled $\times$ C. nasus & St. Petersburg, Russia & $?$ & $\begin{array}{l}\text { 'Most of the females were } \\
\text { false hermaphrodites' }\end{array}$ \\
\hline Ruhlé (1983) & C. lavaretus & Lake Walen, Switzerland & Lobular type & Single case \\
\hline $\begin{array}{l}\text { Hoffmann \& } \\
\text { Meder (1988) }\end{array}$ & C. makrophthalmus & Koenigsee, Germany & Mosaic type & $\begin{array}{l}\text { Single case } \\
\text { ( } 1 \text { out of } 80)\end{array}$ \\
\hline $\begin{array}{l}\text { Brown \& } \\
\text { Scott (1988) }\end{array}$ & C. lavaretus & Loch Lomond, Scotland & Lobular type & $\begin{array}{l}\text { Single case } \\
\text { ( } 1 \text { out of } 7500)\end{array}$ \\
\hline $\begin{array}{l}\text { Demska-Zakes } \\
\text { \& Mamcarz (1996) }\end{array}$ & $\begin{array}{l}\text { C. peled } \times \\
\text { C. lavaretus }\end{array}$ & Lake Leginskie, Poland & Lobular type & Approx. 15 out of 329 \\
\hline \multirow[t]{2}{*}{$\begin{array}{l}\text { Mikaelian et al. } \\
(2002)\end{array}$} & C. clupeaformis & St. Lawrence River, Canada & Lobular and mosaic type & $\begin{array}{l}1.2 \% \\
(6 \text { out of } 497)\end{array}$ \\
\hline & & & $\begin{array}{l}\text { Ovaries with ducts } \\
\text { Containing cells of the } \\
\text { Male germ cell line }\end{array}$ & $\begin{array}{l}11.7 \% \\
\text { (26 out of } 223)\end{array}$ \\
\hline $\begin{array}{l}\text { Kinnison et al. } \\
(2000)\end{array}$ & Coregonus sp. & Review & - & - \\
\hline Bogdanova (2002) & C. peled $\times$ C. nasus & Fishfarm in Leningrad, Russia & Mosaic type & Several \\
\hline Wissmath (2004) & Coregonus lavaetus & Lake Seehamer, Germany & Lobular type & Single case \\
\hline
\end{tabular}

Individuals with hermaphroditic gonads have also been noticed in whitefish populations in European Lakes: Loch Lomond, Scotland (Scott 1975, Brown \& Scott 1988); Koenigsee, Germany (Hoffmann \& Meder 1988); Lake Seehamer, Germany (Wissmath 2004); Lake Leginskie, Poland (Demska-Zakes \& Mamcarz 1996); Lake Osensjoen, Norway (O. T. Sandlund pers. comm.); Gulf of Bothnia, Finland (A. Huhmarniemi, cited in Escher 2001); Lake Pyhäjärvi, Finland (P. Vuorinen, cited in Escher 2001). The same has been reported in North America-Newfoundland (Chen 1969), Lake Michigan (Edsall 1970), Lake Huron (Porter \& Corey 1974), Lake Simcoe (F. Amstaetter, cited in Escher 2001), St. Lawrence River (Mikaelian et al. 2002) - and in Russia (e.g. Statova \& Tomnatik 1970, Semenov 1980, Bogdanova 2002). In all the cited studies, the frequency of hermaphroditic gonads was generally low, with values of $1 \%$ or less (Table 5) except for 2 studies: Semenov (1980) reported that 'most of the females were false hermaphrodites'. This citation comes from the English abstract of the Russian publication, which did not allow us to clarify the meaning of the expression. Additionally, Mikaelian et al.
(2002) observed in a polluted stream in Canada that $1.2 \%(6 / 497)$ of the whitefish sampled were hermaphrodites showing the lobular and mosaic type, and that $11.7 \%(26 / 223)$ of the whitefish possessed ovaries with small areas of testicular tissue, usually present as a few nests of closely packed spermatids, spermatocytes and/or spermatozoas at the periphery of the gonads. In the present investigation of coregonids from Lake Thun, 19 hermaphroditic fish were observed. Excluding the 10 hermaphroditic specimens selectively sampled by professional fisherman during the filleting process, a prevalence of $1.1 \%$ can still be calculated.

Alterations in the normal gonad anatomy, such as gonadal constriction, compartmentation, asymmetry, atrophy and adhesions/fusion to the trunk musculature, were more frequent than hermaphroditic gonads in coregonids from Lake Thun. Similar alterations are described for a number of wild fish populations. In a survey of salmonids from the Great Lake drainage basin in North America, unilateral and, to a lesser extent, bilateral constrictions of the testes were found (Fitzsimons \& Cairns 2000). The prevalence of morphological changes ranged from 28 to $44 \%$ in the Great 
Lakes, and from 2.8 to $13.7 \%$ in the inland lakes. The presence of testicular anomaly could not be related to the rearing history (hatchery-reared versus native lake stock), age, strain or year, at least not for the investigation period 1979 to 1985 (Fitzsimons \& Cairns 2000). The salmonids were affected in the following order: lake trout Salvelinus namaycush $>$ brown trout Salmo trutta and rainbow trout Oncorhynchus mykiss > coho salmon O. kisutch and chinook salmon O. tshawytscha. Coregonids from these lakes also showed morphologically similar gonadal anomalies. Unfortunately, their prevalence was not determined. According to Ruby \& Cairns (1983), constrictions form when spermatogonia within an adjacent group of lobules fail to undergo mitosis, hypertrophy and are subsequently resorbed.

Compartmentations and constrictions have also been reported for lake whitefish Coregonus clupeaformis from Lake Simcoe (F. Amstaetter, cited in Escher 2001; about $10 \%$ of 99 fish affected) and in male whitefish from Lake Kilpisjärvi, Finland (A. Tolonen, cited in Escher 2001; about $30 \%$ of 3000 fish examined over several years). In Switzerland, constrictions, but no compartmentations, have been observed in whitefish from Lake Biel, Lake Sarnen, Lake Lucerne, Lake Lungern and Lake Neuchâtel with a prevalence of approximately $10 \%$ (Centre for Fish and Wildlife Health, Bern, unpubl. data).

Aplasia, atrophy and asymmetry of gonads in whitefish have been described in whitefish from Lake Leginskie, Poland (Demska-Zakes \& Mamcarz 1996); $66 \%$ of 329 whitefish showed an under development or lack of one of the gonads. The authors attributed the malformations to hybridisation of the native European whitefish Coregonus lavaretus with the introduced Peled whitefish C. peled. Asymmetry and atrophy were also a common feature of gonad alterations in lake whitefish C. clupeaformis from Lake Simcoe, Canada (F. Amstaetter, cited in Escher 2001), where 11 out of 99 fish revealed asymmetries and 1 out of 99 fish had only 1 gonad. Asymmetric gonads have also occurred in whitefish from Lake Constance (R. Roesch pers. comm.) and Koenigsee (Meder 1984) in Germany, but in the latter study the gonad weight of the 2 strands did not differ significantly within the population.

To our knowledge, there are no published reports of the adhesion/fusion of parts of the gonads with the lateral trunk musculature in whitefish.

The repeated occurrence of gonadal alterations in whitefish populations from different geographical regions suggests that alterations at a low rate may be a natural phenomenon in whitefish. However, the high frequency and the remarkable diversity of different features in whitefish from Lake Thun appears to be well beyond the levels of gonadal alterations in whitefish reported in the literature or in personal communi- cations. Therefore, the situation in Lake Thun raises the question of what causes these gonadal anomalies.

We propose several hypotheses as potential explanations for the high levels of gonadal alterations in whitefish from Lake Thun.

Genetic disorders. Hermaphroditism is said to appear regularly in fish hybrids, probably due to a disturbance in the balance of sex-determining factors (Chevassus 1983). Genetic defects arising from hybridisation were suspected to be the cause of pronounced gonadal alterations (hermaphroditism, atrophy, aplasia and asymmetry) in whitefish from an oligotrophic lake in Poland resulting from hybridisation of the native whitefish Coregonus lavaretus with an introduced whitefish, C. peled (Demska-Zakes \& Mamcarz 1996). Gonadal abnormalities in oogenesis, such as hermaphroditism, degeneration of oocytes and prohibited differentiation of ovaries, have been described in C. peled $\times$ C. nasus hybrids (Bogdanova 2002). Constrictions of testes have also been reported for salmonid hybrids (Buss \& Wright 1957). In addition, genetic factors are suspected to be involved in the gonadal constrictions prevalent among salmonids in the Great Lakes (Fitzsimons \& Cairns 2000).

Recent genotypic examinations of the central alpine Coregonus species have revealed that the indigenous Coregonus populations of Switzerland are distinct, with their closest relatives within the same lakes (Douglas et al. 1999). The significant differences in allele frequency found among the different ecotypes in Lake Thun indicates a reduced gene flow among phenotypically divergent sympatric populations (Douglas et al. 1999). However, it has been genetically demonstrated that stocking of the Lake Thun during the last $100 \mathrm{yr}$ with non-indigenous coregonids must have taken place (Douglas et al. 1999). The introduced population clustered within the group containing their population of origin, but did not associate directly with their source, thus indicating post-introduction genetic divergence (Douglas \& Brunner 2002). However, since 1946, stocking of non-indigenous coregonid species in Lake Thun has been prohibited. Whether, and to what extent, such a genetic exchange with non-indigenous coregonids from another Swiss lake might have contributed to gonadal abnormalities found in whitefish from Lake Thun remains to be determined.

Hatchery management effects on stocked fish. Lake Thun is intensively stocked with hatchery-reared indigenous coregonids. Eggs and sperm are collected from mature fish from the lake, followed by fertilisation and larval rearing in hatcheries and subsequent release of the young fish into the lake. Gonadal alterations might originate from manipulation of the stocked fish during their rearing in the hatcheries. However, only the ecotype 'Albock' is stocked and this 
ecotype appears to be significantly less affected than the other 2 ecotypes present in Lake Thun (Table 2). This observation argues against hatchery management effects as a causative factor.

Abrupt temperature changes. Changing thermal regimes are known to be environmental modulators of sexual differentiation, germ cell development and gonadal morphology in fish (Goto et al. 2000, Luksiene et al. 2000). Due to the lack of temperature data on the spawning grounds of the whitefish, we have no information to date with which to examine this hypothesis.

Infectious diseases. Infection of roach Rutilus rutilus with the microsporidian parasite Pleistophora mirandellae has been found to be associated with gonadal impairment, including asynchronous development of oocytes and ovarian atresia (Wicklund et al. 1996). Neither Pleistophora mirandella nor any other infective agents were diagnosed in the histologically examined gonads of whitefish from Lake Thun.

Environmental contamination. Exposure of juvenile roach to endocrine-active effluents of a sewage treatment plant induces feminisation of reproductive ducts in male fish (Rodgers-Gray et al. 2000). In field surveys of flounder Platichthys flesus in UK estuaries, phenotypic male fish with unilateral intersex gonads or with ovarian follicular components in the testes were observed (Allen et al. 1999a,b, Simpson et al. 2000). In a PCB-contaminated Swedish lake, perch Perca fluviatilis displayed severe gonadal anomalies (Forlin \& Norrgren 1998). A causative role of environmental oestrogens or androgens in gonadal anomalies of whitefish Coregonus clupeaformis from the St. Lawrence river has been discussed by Mikaelian et al. (2002). For Lake Thun, we currently have no evidence of elevated levels of endocrine-active substances in the lake water or sediments. However, a conclusive statement on this hypothesis is not possible, unless more data on the presence of endocrine-active compounds in the water, sediment or food of the fish becomes available.

In summary, a number of exogenous factors such as temperature, hatchery effects, parasites or chemicals, as well as genetic defects due to hybridisation, have been shown to be able to induce complete sex change, intersex gonads or gonadal anomalies. From these factors, the parasite and the hatchery effect hypotheses appear to be unlikely causes of the gonadal abnormalities of Lake Thun coregonids (see above). For the other factors, however, no conclusive statement on their contribution is currently possible. Therefore, follow-up studies are needed to find the causative factors of the gonadal alterations in whitefish from Lake Thun. One important element of this is to evaluate whether the alterations are restricted to whitefish from Lake Thun, or whether they occur in other Swiss lakes as well. Ongoing work in our laboratory will extend the available database.
Exposure experiments in 2 Swiss lakes are planned: fish hatchlings originating from Lake Thun and other lakes will be kept in cages in Lake Thun for a period of 3 yr. A parallel exposure trial will be done in a second lake, where no such alterations have been observed. These cages will be stocked with fish originating from Lake Thun and from the native lake. This study design should enable us to distinguish the roles of genetic disorders and water quality in aberrant gonadal development in whitefish from Lake Thun.

Acknowledgements. We are grateful to the members of the Fisheries Department Bern for their co-operation, the sampling of fish at Lake Thun and for financial support. The help and assistance with the literature search by the following people is gratefully acknowledged: Dr. M. Escher; Dr. C. Ruhlé, Fisheries Department St. Gallen, Dr. J. Schwaiger, Bavarian State Office of Water Management, and Prof. Dr. Holm, Project 'Fishnet' Switzerland. This study was funded by the 'Stiftung zur Förderung der wissenschaftlichen Forschung an der Universität Bern'. J. Casey and P. Girling are gratefully acknowledged for the English corrections.

\section{LITERATURE CITED}

Allen Y, Matthiessen P, Scott AP, Haworth S, Feist S, Thain JE (1999a) The extent of oestrogenic contamination in the UK estuarine and marine environments - further survey of flounder. Sci Total Environ 233:5-20

Allen Y, Scott AP, Matthiessen P, Haworth S, Thain JE, Feist S (1999b) Survey of estrogenic activity in United Kingdom estuarine and coastal waters and its effects on gonadal development of the flounder Platichthys flesus. Environ Toxicol Chem 18:1791-1800

Baroiller JF, Guiguen Y (2001) Endocrine and environmental aspects of sex differentiation in gonochoristic fish. Experientia Suppl 9:177-201

Blazer VS (2002) Histopathological assessment of gonadal tissue in wild fishes. Fish Physiol Biochem 26:85-101

Bogdanova VA (2002) Ontogenesis of gonads in Coregonus peled (Gmelin) x Coregonus nasus (Pallas) hybrids. Arch Hydrobiol Spec Issues Adv Limnol 57:243-252

Brown EAR, Scott DBC (1988) A second hermaphrodite specimen of Coregonus lavaretus (L.) (Salmonidae, Coregoninae) from Loch Lomond, Scotland. J Fish Biol 33:957-958

Buss K, Wright JE (1957) Appearance and fertility of trout hybrids. Trans Am Fish Soc 87:172-181

Chen MY (1969) A record of hermaphroditism in lake whitefish, Coregonus clupeaformis. J Fish Res Board Can 26: $2521-2523$

Chevassus B (1983) Hybridization in fish. Aquaculture 33: $245-262$

Demska-Zakes K, Mamcarz A (1996) Gonadal abnormalities in Coregonus peled Gmel. $\times$ Coregonus lavaretus L. hybrids, introduced into natural waters. In: Kirchhofer A, Hefti D (eds) Conservation of endangered freshwater fish in europe. Birkhauser, Basel, p 225-232

Douglas MR, Brunner PC (2002) Biodiversity of central alpine Coregonus (Salmoniformes): impact of one-hundred years of management. Ecol Appl 12:154-172

Douglas MR, Brunner PC, Bernatchez L (1999) Do assemblages of Coregonus (Teleostei: Salmoniformes) in the Central Alpine region of Europe represent species flocks? Mol Ecol 8:589-603 
Edsall TA (1970) A hermaphroditic coregonine from Lake Michigan. Trans Am Fish Soc 99:611

Escher M (2001) Gonadenveränderungen bei Felchen aus dem Thunersee. Literaturrecherche und Empfehlung. Report for the Fisheries Inspectorate Bern, Switzerland

Fitzsimons JD, Cairns VW (2000) Prevalence of a testicular anomaly in Lake Trout (Salvelinus namaycush) of the Great Lakes Basin. J Gt Lakes Res 26:74-81

Florin J (1945) Bemerkungen zum Fund eines zwittrigen Grossfelchens (Féra) aus dem Genfersee. Schweiz FischZtg 5:134-138

Forlin F, Norrgren L (1998) Physiological and morphological studies of feral perch before and after remediation of a PCB contaminated lake — Lake Järnsjön. Ambio 27:411-418

Goto R, Abe Y, Masai K, Yamaha E, Adachi S, Yamauchi K (2000) Effects of environmental factors on sex differentiation in goldfish Carassius auratus. In: Norberg B, Kjesbu OS, Taranger GL, Andersson E, Stefansson SO (eds) Reproductive physiology of fish. Proc 6th Int Symp. Department of Fisheries and Marine Biology, University of Bergen, Bergen, p 334

Hoffmann R, Meder D (1988) Seasonal morphological studies on gonads of fish in an alpine lake, the Koenigsee West Germany. Arch Hydrobiol 113:61-92

Hunter JR, Macewicz BJ (1995) Rates of atresia in the ovary of captive and wild northern anchovy, Engraulis mordax. Fish Bull Calif Dep Fish Game 83:119-136

Jobling S, Nolan M, Tyler C, Brighty G, Sumpter JP (1998) Widspread sexual disruption in wild fish. Environ Sci Technol 32:2498-2506

Johnson RD, Tietge JE, Jensen KM, Fernandez JD and 7 others (1998) Toxicity of 2,3,7,8-tetrachlorodibenzo-p-dioxin to early life stages of brook trout (Salvelinus fontinalis) following parental dietary exposure. Environ Toxicol Chem $17: 2408-2421$

Kime DE (1998) Endocrine disruption in fish. Kluwer, Boston

Kinnison MT, Unwin MJ, Jara F (2000) Macroscopic intersexuality in salmonid fish. N Z J Mar Freshw Res 34:125-134

Kirchhofer A (1995) Growth characteristics of coregonid populations in three lakes with different trophic states and decreasing nutrient concentrations. Adv Limnol 46:61-70

Kirchhofer A, Lindt-Kirchhofer TJ (1998) Growth and development during early life stages of Coregonus lavaretus from three lakes in Switzerland. Adv Limnol 50:49-59

Kitano T, Takamune K, Kobayashi T, Nagahama Y, Abe SI (1999) Suppression of P450 aromatase gene expression in sex-reversed males produced by rearing genetically female larvae at a high water temperature during a period of sex differentiation in the Japanese flounder (Paralichthys olivaceus). J Mol Endocrinol 23:167-176

Kottelat M (1997) European freshwater fishes. An heuristic checklist of the freshwater fishes of Europe (exclusive of former USSR), with an introduction for non-systematists and comments on nomenclature and conservation. Biologia (Bratisl) 52(Suppl 5):1-271

Luksiene D, Sandström O, Lounasheimo L, Anderson J (2000) The effects of thermal effluent exposure on the gametogenesis of female fish. J Fish Biol 56:37-50

Matthiessen P, Allen Y, Bamber S, Craft J and 9 others (2002) The impact of oestrogenic and androgenic contamination on marine organisms in the United Kingdom - summary of the EDMAR programme Endocrine Disruption in the Marine Environment. Mar Environ Res 54:645-649

Meder D (1984) Morphologische Untersuchungen an den Gonaden der wichtigsten Fischarten im Königsee. Dissertation, Ludwig-Maximilians University, Munich

Editorial responsibility: Thomas Braunbeck, Heidelberg, Germany
Mikaelian I, Martineau D, De Lafontaine Y, Harshbarger JC, Lee LLJ (2002) Health of lake whitefish (Coregonus clupeaformis) with elevated tissue levels of environmental contaminations. Environ Toxicol Chem 21:532-541

Noaksson E, Tjärnlund U, Bosveld ATC, Balk L (2001) Evidence for endocrine disruption in perch (Perca fluviatilis) and roach (Rutilus rutilus) in a remote Swedish lake in the vicinity of a public refuse dump. Toxicol Appl Pharmacol 174:160-176

Norrgren L, Bengtsson BE, Börjeson H (1994) Summary of the workshop 'Reproduction disturbances in fish'. In: Norrgren L (ed) Report from the Uppsala workshop on reproduction disturbances in Fish, Swedish Environmental Protection Agency, Report 4346, Solna, p 7-11

Patino R, Davis KB, Schoore JE, Uguz C, Struessmann CA, Parker NC, Simco BA, Goudie CA (1996) Sex differentiation of channel catfish gonads: normal development and effects of temperature. J Exp Zool 276:209-218

Porter TR, Corey S (1974) A hermaphroditic lake whitefish, Coregonus clupeaformis, from Lake Huron. J Fish Res Board Can 31:1944-1945

Rodgers-Gray TP, Jobling S, Kelly C, Morris S, Brighty G, Waldock M, Sumpter JP, Tyler CR (2000) Exposure of juvenile roach, Rutilus rutilus, to treated sewage effluent induces dose-dependent and persistent disruption in gonadal development. Environ Sci Technol 35:462-470

Ruby SM, Cairns VW (1983) Implications of testicular constrictions on spermatogenesis in Lake Ontario lake trout, Salvelinus namaycush. J Fish Biol 23:385-395

Ruhlé C (1983) Bemerkungen zum Fund eines zwittrigen Kleinfelchen (Albeli, Coregonus lavaretus L.) aus dem Walensee. Fisch Fischerei 1:2

Sandström O, Neuman E, Karas P (1988) Effects of a bleached pulp mill effluent on growth and gonad function in Baltic coastal fish. Water Sci Technol 20:107-118

Scott DBC (1975) A hermaphrodite specimen of Coregonus lavaretus (L.) (Salmoniformes, Salmonidae) from Loch Lomond, Scotland. J Fish Biol 7:709

Semenov W (1980) Dependence of vitellogenic oocytes growth rate in coregonid fish upon functional condition of liver cells. Arkh Anat Gistol Embriol 78:98-107

Simpson MP, Parry M, Kleinkauf A, Swarbreck D, Walker P, Leah RT (2000) Pathology of the liver, kidney and gonad of flounder (Platychthys flesus) from a UK estuary impacted by endocrine disrupting chemicals. Mar Environ Res 50: 283-287

Statova MP, Tomnatik EN (1970) Process of anatomical and cytological sex differentiation in peled, Coregonus peled (Gmelin). Izv Mold fil AN USSR 1:36-39

Steinmann P (1948) Ein vollreifer Felchenzwitter. Schweiz Fisch-Ztg 57:15-16

Steinmann P (1951) Monographie der schweizerischen Koregonen. Beitrag zum Problem der Entstehung neuer Arten. Spezieller Teil (2nd part). Schweiz Z Hydrol 13:54-191

Vethaak AD, Rijs GBJ, Schrap SM, Ruiter H, Gerritsen A, Lahr $\mathrm{J}$ (2002) Estrogens and xeno-estrogens in the aquatic environment of the Netherlands. Occurrence, potency and biological effects. Report no. 2002.001, RIZA/RIKS, Lelystad

Wicklund T, Bylund G (1994) Reproductive disorder in roach (Rutilus rutilus) in the Northern Baltic Sea. Bull Eur Assoc Fish Pathol 14:159-162

Wicklund T, Lounasheimo L, Lom J, Bylund G (1996) Gonadal impairment in roach Rutilus rutilus from Finnish coastal areas of the northern Baltic Sea. Dis Aquat Org 26:163-171

Wissmath (2004) Hermaphrodit im Seehamer See. Fisch Teichwirt 1:508

Submitted: December 15, 2003; Accepted: June 9, 2004

Proofs received from author(s): September 16, 2004 